\title{
Customer Behavior and Attitude Assessment for Green Practices in lodging Industry at India
}

\author{
Abhinav Mishra, Dr. Sunishtha Dhaka, Mukesh Shekhar
}

\begin{abstract}
Green programs become more effective and efficient by acquiring the in depth knowledge of customers' desire for participation in green activities. This paper provides the assessment of guests' that are staying in hotel with their environmentally friendly approaches that influenced the intentions. Second, this research estimates the customer barriers for participation such as reduced luxury, cost cutting perceptions and inconvenience. Such parameters are significantly influence the intention of consumers' and make the decision on whether to stay at a green hotel or spend additional cost for a room in such a hotel. Third, the work depicts that customers never consider the importance of green practices connected with staying in a hotel whether they believe the requirements. Fourth, the survey report shows that customers take the responsibility of environment much enthusiastically for home rather than a hotel. These findings are important for providing the relevance of actions and communication of hotel managers' to guests' concerning by cost cutting perceptions reduction, increasing participation accessibility in green programs, and educating customers about green practices.
\end{abstract}

Keywords : Consumer behavior, Customer Attitude, Corporate social responsibility, Environment, Green practices, Hotel industry, Tourism.

\section{INTRODUCTION}

I ndia is the main attraction of tourism industry. Millions of tourists and travelers are coming in India as well as the same citizens are also travelling a lot in the country. Tourism is one of the highest revenue-providing sector. Due to such highly competitive environment that is rigorously increasing, demands the pro-green practices in hotels to develop an eco-friendly system. The "green" hotel business model is a flourishing niche due to the fulfilment of the requirement in domain of less environmentally damaging hotels and discriminate themselves with the analogous non-green hotels. Green hotel and environment-friendly hotel have developed a commitment towards several ecologically sound practices like lessen solid waste, energy saving and water saving (www. hometravelagency.com). Nowadays, people are more aware about the ecological damage during their stay on regular business activities. Due to this, the hotel industry are ready to take the responsibility and reducing the wasting/harming of environmental resources. This results as more customers are

Revised Manuscript Received on December 18, 2019.

* Correspondence Author

Abhinav Mishra*, Department of Hotel Management, Manipal University Jaipur, Jaipur, India. Email: abhinavmishra10@gmail.com

Sunishtha Dhaka, Department of Commerce, Manipal University Jaipur, Jaipur, India. Email: dsunishtha@gmail.com

Mukesh Shekhar, Department of Hotel Management, Manipal University Jaipur, Jaipur, India. Email: mukeshshekhar28@gmail.com

searching the hotels that follow the green practices to save environment. The first step for becoming the foundation, a green hotel adopts great marketing strategy as offering their consumers with what they require. Green hotels have the base of growing consumer. Therefore, such practices help the hotel to create a position distinctively among the market place. In literature, researchers illustrated that consumers are ready to opt an environment friendly hotel over a standard hotel. They just need to offer the similar establishments between the two. Hotel will catch the combination of customers as well as the people who support the environmentally sensitive practices. Indian hospitality industry has a very limited documentation that encourages the researchers/authors for customer's behavior identification and analysis towards environment friendly hospitality lodging practices.

\section{OBJECTIVE}

In India, it is important to explore the lodging industry for conducting green practices with the aspects of influence at consumer behavior and attitude towards them. Furthermore, it also scrutinizes the intentions of consumers' in order to pay for green practices. This paper provides the assessment on several parameters contributing to customer's behavior and attitude towards green hotels. This comprehensive study makes the analysis on customers that whether they are ready to stay and spend on such hotels pursuing the green practices. This study highlights the lacking of awareness between the people about the environmental initiatives that is also a cost saving approach for hotels. This study outlines the insights and crucial facts of Indian lodging industry with data on consumer dynamics regarding green practices. This paper is an attempt to outline some significant facts of Indian hotel industry regarding green practices and observations on behavior of customer-buying towards such approaches. In India, the primary resources of green practices are sanitation and water. The tourism industry requires to absorb green practices as business model. Such model has a big responsibility of sustainability for a long run..

\section{LITERATURE REVIEW}

Kotler [1] proposed that the product choices of customers depending on their requirements of product attributes such as prior, satisfaction, cost and dimensions of value. Product attributes are considering as peripheral that offer supplementary benefits, auxiliary or core attributes that give the basic benefits sought by customers. 


\section{Customer Behavior and Attitude Assessment for Green Practices in lodging Industry at India}

Fuller [2] suggested that such attributes are significant for differentiation and offering benefit to the hotel industry. According to the perspective of customer, the product of hospitality and tourism have the core attributes involving their functional performance and offering the secondary benefits as nonessential attributes. Environmental performance depends on nonessential attributes. This performance also connects with the aspect of product such as alternate source of energy utilization or water disposal and may deliver a prospect of differentiation in products.

Some researchers like McDaniel and Rylander [3] propose the reconsideration of "needs" and "wants" of consumers in context of sustainability of environment with the best interests of society meanwhile ignoring the long-term factors without affecting the customer satisfaction. Kotler [1] proposed the concept as "The perception of societal marketing carries that the administration's action is to estimate the interests, desires and requirements of aim markets and to bring the anticipated consummations more efficiently and effectively as compared with the competitors in a manner that advances and conserves the society's and the consumer's well-being". However, it is not possible to deliver the 100 percent environmentally friendly as the hospitality product. Particularly, it realizes the environmental benefits with the marketing strategies as the selling of products according to consumer satisfaction and the fulfillment of consumer expectations for eco-friendly products. "Environmentally-friendly" products should lessen the destructive influence on atmosphere. Hindle et al. [4], Pujari, and Wright [5] gave some specifications to deliver quantifiable developments all over the lifecycle of entire product. These becomes the more efficient technologies as the process or technology change with "cleaner" development. Such product has the aspects of disposability, repair or remanufacture, designed for reuse, biodegradable and recyclable. Shrivastava [6] proposed the other parameters of product as its health and safety measures, the quantity of pollution production, disposal means, how the product is used, waste production and the raw materials selection. The significance of environmental benefit may vary as either more or less depending on the expansion of product-life, energy conservation, pollution avoidance and contraction of source.

Many environmentalists and ecologists shown their interest in adopting the "Green" lifestyles from the instant when they witnessed the initial sight of the Earth from space during the space programme. Some of them were showing their awareness towards the fragility of the planet. The individuals knowledge enhance with the passing of time that make them more aware towards the conservation of resources as the life on Earth is special. Last two decades provide the raised in awareness in humans concerning for environment. Due to this several terminologies and factors are identified as "Greenhouse effect", "Acid rain" and "Ozone depletion".

Hotel construction, operations and facilities make most of the destructive influences on the atmosphere. The success rate of hotel industry and tourism highly based on the accessibility of a clean environment. Location of hotels in specific environment consume several natural resources (non-biodegradable and biodegradable) to that region. Hotel premises release the gaseous and liquid discharges/emissions with different types of solid wastes depending on the consumption of resources. Different environment has different hotel operations such as beach resorts, mountains, desert, metro cities etc. Several resources are getting consumed due to the use of different operations under such a variety of environments. Due to such unbalanced manner of environmental resource consumption develops overload on supporting atmosphere. Conventionally, "green marketing" concept exaggerated claims about the impact of product's environmental and seemed to be the one associated with hype instead of the products having positive information. Peattie [7] and Welford [8] gave the responsibility of process management about "green marketing" for the requirements of society and customers satisfaction, anticipation and identification, in a sustainable and profitable manner. Indian ecotourism has important inferences for rural livelihood and culture/nature conservation. Hotel industry has the responsibility of stimulating the environmental responsibility. However, it seems like Indian hotel industry carries the environmental performance depending on the international practice.

Environmental issues show their relevance for Indian hotels, as they worldwide become competitive success in tourism firms and destinations. Indian hotels must fulfill the needs of environment targeting markets leads to enhance their environmental performance in order to attain the ecological/general competitiveness on a global tourism market. Foster et al. [9] suggested that tourism industry and hospitality are becoming more environmentally friendly in under pressure from the following forces:

- Aesthetics need

- Issues regarding physical plant maintenance

- Consumer demand

- Consumer satisfaction

- Environmental regulation enhancement

- Managerial concern with ethics.

Roarty [10] suggested the addition factors exerting pressure for variations as: in environmental pressure groups as the "disproportionate influence on consumer behavior" and exposure limitation for environment risk by enhancing the impact of the "green" investor involving banks.

In literature on tourism and hospitality industry on environmental management, there are number of citations available. However, most of the citations denote the abating future cost issues related by saving resources and cost reduction. Ton et al. [11], Forte [12], Green Globe [13], Middleton and Hawkins [14], Kirk [15] provided their functional publications, corporate communications and hotel press releases through the International Hotels Environment Initiative. Tourism and hospitality industry have the cost issues that are not so perceptible in theoretical studies. This may be because of typical low return on investment and obsession with high fixed costs of this industry.

"Smokestack" industries are initially the main part of tourism industry. 
However, now circumstances deal with the environmental impacts by tourism. Tourism industry responsible for 11 percent of world's GDP according to the WTTC $(1999,2000)$ and considered as the largest industry of the world, directly creating 200 million jobs globally. It is also one of the fastest rising industries having the advance rate of 6 percent per year approximately [16]. Engine for economic development considering the tourism as its main source. Furthermore, since 1998, tourism responsible for 30 percent of international arrival and rising fastest in the developing world. Such growth shows their importance where the governments have not any priorities for enforce legislation and regulation for the protection of environment as tourism development. Ottman [17], Schlegelmilch et al. [18], Wong et al. [19], and Roy [20] proposed the documentation on the consideration of eco-friendly products according to the choice of consumers with purchasing repertoire. They are comfortable with the performance of conventional products with good feedbacks on key attributes like cost, convenience, quality and functional performance.

Researchers have proposed early "failure" works for numerous ecological friendly goods that ensure the customers that the functional performance of product was partly attributable. However, some customers consider lesser functional performance during the purchase of environment friendly product. Therefore, this type of purchasing has no primary motivation with no primary benefit towards the environmental. Wong et al. [19] gave a theory that "'Green' is seldom the over-riding determinant of brand choice or product however just another advantage or aspect that integrates value, generally a 'feel good' aspect to the whole product". According to the further research on this theory, there was a conclusion that only location of environment was enough to product success guarantee.

Consumer retention and adoption of environmental products are getting influenced by the performance of product. Therefore, the expectations of customers have not coordinated up to the in-use experience. It means a performance gap exists of the existence of relative performance regarding consumer skepticism of environmental products. Such factor strongly affects the acceptance of product. With the context of environment, a successful competitive strategy if product differentiation. For example, the success of product depending on the selection of packaging, product attributes or/and product positioning for making differentiation. However, environmental benefit products also affects such attributes (Leigh et al., [21]; Shrivastava, [6]). Environmental benefits may estimate the selection and preference of consumer for the perceiving of two products at a time in equal quantity with an exception that one has superior environmental performance (Kardash, [22]; Ottman [17]). This differentiation strategy is specifically significant for markets facing the extreme rivalry (Menon et al. [23]) or it becomes very problematic for products to discriminate themselves (Christensen [24]). The performance of such environment friendly product may influence the choice of consumer with the providence of different point of view.

There is a resistance in adopting the pro-environmental behavior due to the conflicts and constraints during the purchasing of environmentally-friendly products. For example, consumers may need to uphold their present life-style with the responsibility towards environment (Schwartz [25], McDaniel and Rylander [3]). They may not be interested in spending a cost or accepting the lower performance levels and sacrificing their convenience. According to a theory on consumers behavior planning (Ajzen's [26]), there ae number of factors that influence the intentions and behavior of environmental purchasing. For example, the prospect to perform in an ecological friendly manner, the ability to perform the behavior and the motivation/knowledge of individual (Pieters [27], $\mathrm{O} *$ lander and Thøgersen, [28]).

According to some reports, many hotels charge a premium cost on the name of ecological friendly goods so as to recover the additional disposal, marketing and production cost. This may consist the cost of initial set-up for the production and distribution process of novel or substitute more environmental friendly products; reuse and remanufacture; product recapture expenses; or to attain the economical scale with the recovery of indirect costs (at least initially) (Wong et al. [19], Fuller [2], Peattie [7]).

Few customers are willing to spend additional on green practices specially those who are more approachable towards environmental products. Few examples on marketplaces also recommended that consumers still not ready to spend the premium charges generally. Therefore, there is a conclusion on the customer approaches that it is always inconclusive and inconsistent. In often, customers will spend on an average around 5 percent more for their usual range (Reinhardt [29]). Some of the groups can spend as much as 20 percent or more on such product for enhancing green practices (Roper Starch Worldwide [30]). This may happen mostly during the sustenance of the perceiving of environmental benefits to make private benefits from which the costumer either personally, directly or exclusively take profit from the practices, in place of public goods that benefit the whole society (Ottman, [17], Gallagher and Kennedy [31], Marcus [32]).

\section{PROPOSED HYPOTHESIS/METHODOLOGY}

In the comprehensive literature survey on green practices, the universal steps to develop the hypothesis is:

H1. Adoption of green practices depending on the optimistic attitude towards such practices in the lodging industry resulting as the optimistic behavior towards the selection of hotel staying.

$\mathrm{H} 2$. The relationship between willingness to pay expenses on green practices and an optimistic consumer attitude towards the same is absent.

H3. The relationship between willingness to pay expenses on green practices and an optimistic consumer behavior towards the same is absent. 


\section{Customer Behavior and Attitude Assessment for Green Practices in lodging Industry at India}

It starts with the conduction of the study on a specific region such as in India mostly in National Capital Region of Noida, Gurgaon and Delhi with the selection of certain sample size of respondents. It has a sequential and structured questionnaire that is required to be developed for studying the consumers behavior and attitude on green practices. Initially, there is a pre-testing of questionnaire on a small group of respondents where some minor modifications performed based on the ambiguous statements of individuals. It has overcome the use of convenience sampling over the budgets and time of constraints. Some of the important aspects used to estimate the parameters in the structured questionnaire are as consumer behavior and attitude during their stay in green hotels. This survey also include the assessment of consumers' willingness to spend on environmental practices for the hotels. This paper also include the assessment on demographic profile of the consumers.

\section{SAMPle Profile}

As discussed that this study needs the samples of demographic profile as an example:

It is necessary to include various categories of age with a good spread of respondents in the sample. For example, this paper has the respondents of majorly youth having the age group of 26 years in 75 percent. It highlights the validation of the sample due to their potential of paying capacity. Such sample also include the respondent having the qualification of post-graduation (96 percent) as the educational profile. Furthermore, such pattern include the group of professionals working in either public or private sectors (about 51 percent). It involves a certain group of self-employed respondents (28 percent). It has the data of the respondents (36 percent) who spend at least 3-5 nights per month in the lodge specifically for corporate purpose. One more sample consists the data of respondents ( 22 percent) who stay 6-7 nights per month in the lodge. The figures depicts that 15 percent respondent spend in resorts, 25 percent in economy hotels, 39 percent in high-end hotels and 13 percent respondents choose luxury hotels. Another consideration is that such sample has the data of family members/size that shows that 40 percent consists the four members in a family, 24 percent have the family size of three and 80 percent stay as nuclear families. Based on their salary, the family has more than the income of Rs. 3 lakhs monthly income is of 60 percent and remaining 40 percent sample has Rs.3 lakhs or less as the salary.

\section{FINDINGS}

Because Because Some of the major findings of this study are:

In the lodging industry, this paper depicts the behavior and attitude of consumers towards the usage of green practices. There are several factors used on green practices for the assessment of consumer expectations in the lodging industry. The main variables used for the reliability assessment of customer behavior are green practices, behavioral loyalty, attitudinal loyalty, customer loyalty, affective, cognitive, customer satisfaction. The level of green practices include the parameters as environmental activities, toxic substance signage, water saving technology, air filtration, energy efficient lighting, recycling program, programmable thermostats, organic food, noise control, awareness programs etc. Some of the variables have contributed significantly in the attitude of consumer towards green practices. For example,

- Encourage the service providers who make their business as much as ecological friendly (i.e. using of substitute vehicle fuel, integrated pest management (IPM), renewable energy).

- Conduct awareness as the noticeable communications on public usage of green practices, vendors, stockholders and their guests

- Offer environmentally friendly products (such as locally or organic made/from, low toxicity etc.)

- Multiple night guests have the option to offer a linen re-use

- All sections of hotels have the recycling program for resources and material

- Encourage business persons to participate in certification program like ISO 9000 and environmental partnership events

Such factors imply the outlook of consumers towards the firm's commitment as tangible demonstration for green practices. It is important to make the correct actions featuring awareness demonstration by the lodging firm. It also depicts about the faking associations with environmental friendly traders, visible steps for resource conservation and provision of environmental friendly services pervade advanced grade of assurance between customers.

It has considered the principle of "sensitivity to the environment" where numerous tourism formations have taken into account the concept of green marketing for several motives like the legal sanctions of states, competitive pressure, consumer trends, natural life impairment and environmental pollution. Bureau Veritas and TUROB (Touristic Hotels and Investors Association) with the association of Environment-Friendly Forum declared Polat Renaissance Hotel-Istanbul ranked first under the category of green hotels as five-star ratings. It was occurred this year in Turkey as the $5^{\text {th }}$ World Water Forum. This project targets to illustrate that how hotels can grab and hold the opportunity beside the choices of consumers over developing environmentally sensitive parameter through saving energy and water and with the help of waste management. Polat Renaissance Hotel attained this position due to significant reduction in its expenses through producing electricity with natural gas engine. It occurs due to the use of exhaust gas heat of the engine by simultaneously hot water and steam production. Furthermore, it conducted the good promotion of this green practices by getting the support from NGOs and eco-sensitive customers. It has very prestigious occasion and honor for the hotel. While, it is also true that enhancing in profits of hotel leads to reduction in its expenses in medium terms. 
Although such actions during the establishment of hotel are significant that consists several sectors in tourism industry globally like recreate actions, accommodation and transportation that have an important place in the release of $\mathrm{CO}_{2}$ gas. The release of carbon dioxide gas is one of the lethal factor for the conduction of green practices all over the world. It becomes the main cause of environmental pollution. According to the report, the tourism industry of worldwide releases $5 \%$ of total carbon dioxide in the atmosphere. Out of this, $75 \%$ includes the transportation (water, land, air and other) in tourism.

The data of literature survey shows that after the transportation sector, the accommodation sector ranks second in the release of carbon dioxide. It is necessary that not damage our own resources for tourism resulting the enhancement of environmental sensitivity and accordingly, the acceleration of green practices for establishment of accommodation. According to Foster et al. [33], green-marketing practices has the following reasons for directing accommodation establishments such as:

- They are willing to eradicate the issues regarding physical appearance.

- Assurance of more customer satisfaction

- Hotel managers take more interest in ethical challenges;

- Enhancement in consumer interests in environmental challenges;

- Enhancement in environment regulations;

Such reasons cause the clear enhancement in accommodation establishments' accordingly for green marketing as similar as the other tourism establishments. Green Hotels Association (1993) targets to deliver such establishments with the environment consciousness according to the international sense. It follows the principle as "to collect hotels in all destinations we enjoy staying in order for them to save water and energy, reduce the amount of their wastes and protect these destinations and to determine policies',[3]. However, green hotel management understanding does not perform the establishment by itself in practice. Therefore, it becomes highly significant to connect with the conscious of customers with green travel. This Association of Green Hotels has an endorsement series to increase customer consciousness towards green travel [4]:

- Some hotels give the services as the electronic procedure for checking out on the television of consumer room. If such service is present in the hotel then utilize it.

- Give the warning to the hotel during events where the lights of places are turned on like tennis court, Jacuzzi, sauna, fitness center etc.

- If the hotel offers the service to provide newspapers daily and if consumer does not want to read them then either leave them in the lobby or give them to others.

- Question them whether they have the facility of recycling program regarding newspapers, magazines and other paper.

- Aware and warn the hotel about changing towels and bed sheets every day for particular person.

- Promote and give rewards to those tour operators who support tourism establishments in airlines, hotels etc. during green programs and recommend them to others.

- On beverages (water, tea, coffee etc.) and other tools/equipment, mention the name of user that they used in the room.

- Contamination will be less if the record is maintained of family member that uses towel. Due to this manner, everybody utilizes her/his personal towel.

- Spend less water by closing the tap while washing hands/faces and taking shower.

- On leaving the room, turn off the light and electronic gadgets such as radio, $\mathrm{TV}$ etc.

- During the stay in the hotel, join and promote the recycling program on waste management.

- Collect your dirty belongings instead of using the washing facilities of hotel and clean them back at home by carrying extra bag.

Do not take the extra bottles of soap and shampoo and leave them in room.

\section{CONCLUSION}

In India, the customers consuming the services of hotel are sensible towards the ecofriendly practices. They support and appreciate the hotels that supports the green practices deprived of negotiating the quality of service. The customers would select to book the lodge that obey sincerely such practices, however, are not ready to spend additional cost for these services. Indian hotels faces the competitive merits over related goods if they trail green practices. Each hotel should follow the concept of environmentally friendly practices for achieving the long-term gains. Governing bodies should require to appreciate these efforts with giving tax benefits and institutional rewards. Each process starts with a making of good questionnaire with the usage of qualitative and quantitative research methodology. This study provides the report of National Capital Region of India including the convenience-sampling techniques especially for the assessment of a structured questionnaire. Exploration of the data from lodging industry going for the factor analysis and correlation processes for the detection of consumers' behavior and attitudes towards green practices.

\section{REFERENCES}

1. P. Kotler, Marketing Management: Analysis, Planning, Implementation, and Control, 9th ed., Prentice-Hall, Upper Saddle River, NJ. Hall, 1997.

2. D. A. Fuller, Sustainable Marketing: Managerial-Ecological Issues, Sage Publications, Thousand Oaks, CA, 1999.

3. S. W. McDaniel and D. H. Rylander, "Strategic green marketing", The Journal of Consumer Marketing, Vol. 10 No. 3, pp. 4-11, 1993.

4. P. Hindle, P. White and K. Minion, "Achieving real environmental improvements using value-impact assessment", Long Range Planning, Vol. 26 No. 3, pp. 36-48, 1993.

5. D. Pujari and G. Wright, "Developing environmentally-conscious product strategy (ECPS): a qualitative study of selected companies in Britain and Germany", Marketing Intelligence \& Planning, Vol. 14 No. 1, pp. 19-28, 1996.

6. P. Shrivastava, "Environmental technologies and competitive advantage”, Strategic Management Journal, Vol. 16, pp. 183-200, 1995.

7. K. Peattie, Environmental Marketing Management: Meeting the Green Challenge, Pitman, London, 1995.

8. R. Welford, Hijacking Environmentalism, Earthscan, London, 2000. 


\section{Customer Behavior and Attitude Assessment for Green Practices in lodging Industry at India}

9. S. T. Foster, S. E. Sampson and S. C. Dunn, "The impact of customer contact on environmental initiatives for service firms", International Journal of Operations \& Production Management, Vol. 20 No. 2, pp. 187-203, 2000.

10. M. Roarty, "Greening business in a market economy", European Business Review, Vol. 97 No. 5, pp. 244-54, 1997.

11. M. Ton, M. Lin and D. Radin, Greening Your Property: A Green Seal Guide, Green Seal, New York, NY, 1996.

12. J. Forte, "Environmentally-friendly management in hotels", in Taylor, B., Hutchinson, C., Pollack, S. and Tapper, R. (Eds), Environmental Management Handbook, Pitman Publishing, London, pp. 168-86, 1994.

13. Green Globe, The Green Globe Manual, Green Globe, London, 1994.

14. V. T. C. Middleton and R. Hawkins, Sustainable Tourism: A Marketing Perspective, Butterworth-Heinemann, Oxford, 1998.

15. D. Kirk, Environmental Management for Hotels, Butterworth-Heinemann, Oxford, 1997.

16. A. Mathieson and G. Wall, Tourism: Economic, Physical, and Social Impact, Longman, Harlow, 1996.

17. J. A. Ottman, "Sometimes consumers will pay more to go green", Marketing News, Vol. 26, 1992.

18. B. B. Schlegelmilch, G. M. Bohlen and A. Diamantopoulos, "The link between green purchasing decisions and measures of environmental consciousness", European Journal of Marketing, Vol. 30 No. 5, pp. 35-56, 1996.

19. V. Wong, W. Turner and P. Stoneman, "Market strategies and market prospects for environmentally friendly consumer products", British Journal of Management, Vol. 7, pp. 263-81, 1996.

20. R. Roy, "Designing and marketing greener products: the Hoover case", in Charter, M. and Polonsky, M.J. (Eds), Greener Marketing: A Global Perspective on Greener Marketing Practice, Greenleaf Publishing, Sheffield, 1999.

21. J. H. Leigh, P. E. Murphy and B. M. Enis, "A new approach to measuring socially responsible consumption tendencies", Journal of Macromarketing, Vol. 8 No. 1, pp. 5-20, 1988.

22. W. J. Kardash, "Corporate responsibility and the quality of life: developing the ecologically concerned consumer", in Henion, K.E. and Kinnear, T.C. (Eds), Ecological Marketing, American Marketing Association, Chicago, IL, 1974.

23. A. Menon, A. Menon, J. Chowdhury and J. Jankovich, "Evolving paradigm for environmental sensitivity in marketing programs: a synthesis of theory and practice", Journal of Marketing Theory and Practice, Vol. 7 No. 2, pp. 1-15, 1999.

24. P. D.Christensen, "The environment: it's not time to relax", McKinsey Quarterly, Vol. 4, 1995.

25. J. Schwartz, "Earth day today", American Demographics, Vol. 12 No. 4, pp. 40-1, 1990.

26. I. Ajzen, Attitudes, Personality, and Behaviour, Open University Press, Milton Keynes, 1988.

27. R. G. M. Pieters, Attitudes and Behaviour in a Source Separation Program: A Garbology Approach, Eburon, Delft, 1989.

28. F. Olander and J. Thogersen, "Understanding of consumer behaviour as a prerequisite for environmental protection", Journal of Consumer Policy, Vol. 18 No. 4, pp. 345-85, 1995.

29. F. L. Reinhardt, "Environmental product differentiation: implications for corporate strategy", California Management Review, Vol. 40 No. 4 , pp. 43-73, 1998.

30. Roper Starch Worldwide, Green Gauge Report, Roper Starch Worldwide Inc., New York, NY, 1997.

31. S. Gallagher and N. Kennedy, "Organic foods: pricier, but safer?", Kiplinger's Personal Finance Magazine, Vol. 51, 1997.

32. M. B. Marcus, "Organic foods offer peace of mind . . . at a price", US News and World Report, Vol. 130, p. 130, 2001.

33. S. T. Foster, S. E. Sampson and S. C. Dunn, "The impact of customer contact on environmental initiatives for service firms", International Journal of Operations \& Production Management, Vol. 20 No. 2, pp. 187-203, 2000

\section{AUTHORS PROFILE}

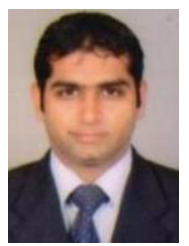

Abhinav Mishra is an alumnus of Institute of Hotel Management, Lucknow, U.P. and holds Bachelor degree in Hospitality and Hotel Administration \& Master degree in various disciplines of Hotel, Tourism \& Business Management. He has been a Certified Learning Facilitator from NCHMCT (Under Ministry of Tourism) \& Hospitality trainer. He has attended Faculty Development
Programs \& workshops on Entrepreneurship development. He has extensive experience of industry \& academics for more than 15 years in both India and abroad with renowned organizations such as Boscolo Plaza Nice, France, Sofitel Hotel Washington DC, USA, SGT University Gurgaon and NCHMCT (Under Ministry of Tourism). He is presently working with Institute of Hotel Management, Lucknow, U.P. as Lecturer in the field of Hospitality. He also has attended many national \& international conferences/seminars \& published research papers in hospitality \& tourism journals/proceedings.

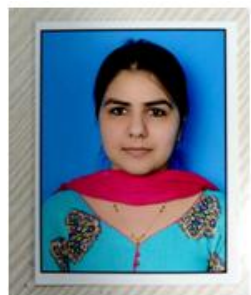

Dr. Sunishtha Dhaka is an alumnus of University of Rajasthan \& holds Bachelor degree in Biotechnology. She has done Master in Business Administration with dual specialization in marketing and human resources. She has done her $\mathrm{PhD}$ with research title Development of Co-Creation Model for Hotel Industry in Jaipur City. Her Ph.D. work centers on exploring the Engagement marketing in services context. She has qualified UGC NET-JRF (2011) in management. She has published eight papers in International and National Journals publication. She has attended and presented papers in various National and International conferences. She also attended Seminars, Faculty development programmes and workshops on Research Methodology, Pedagogy to classroom teaching etc. She has been presently working as Assistant Professor at Manipal University, Jaipur. The Overall industry, research \& academic experience is 9 years.

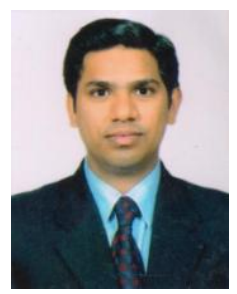

Mukesh is an alumnus of Institute of Hotel Management, Lucknow, U.P. and holds Bachelor degree in Hospitality and Hotel Administration \& Master degree in various disciplines of Hotel, Tourism \& Business Management. He has attended Faculty Development Programs \& workshops in hospitality \& tourism. He has extensive experience of industry \& academics for more than 15 years in India including Trident Hilton, Gurgaon, Rohilkand University, Bareilly. He is presently working with Manipal University as Asst. Professor in the field of Hospitality. He also has attended many national \& international conferences/seminars \& published research papers in hospitality \& tourism journals/proceedings. 